Orlando Ricardo Hung MD FRCPC

\title{
Airway adjuncts and alternative techniques of endotracheal intubation
}

Tracheal intubation is one of the many challenges of an anaesthesia practice. Traditionally, an endotracheal tube (ETT) is placed into the trachea under direct vision using a laryngoscope. The success of laryngoscopic intubation primarily depends upon the experience of the intubator and the anatomy of the patient's upper airway. However, even in the hands of experienced laryngoscopists, intubation under direct vision can sometimes be difficult or even impossible. The incidence of difficult laryngoscopic intubation reported in the literature ranges between 1-3\%.' Many upper airway anatomical features have been identified as predictors of difficult laryngoscopic intubation. However, no single airway variable can reliably predict a patient with difficult laryngoscopic intubation. ${ }^{2}$ While intubation using a fibreoptic bronchoscope has been shown to be effective in patients with difficult airways, it does have some limitations. The fibreoptic intubation equipment, for example, is expensive and the technique requires special training and skill. Furthermore, this technique is difficult to use in emergency situations with "unprepared" and uncooperative patients or in patients with copious secretions or blood in the oropharynx. The continuing challenges of these difficult circumstances have led to the development of many airway adjuncts and alternative techniques of intubation over the past several decades. The primary objective of this presentation is not to provide an exhaustive list of these adjuncts and techniques, but rather to review some old techniques as well as new developments in "blind" tracheal intubation in recent years. It should be emphasized that this presentation reflects only the presenter's experience, bias and the available resources. The choice of a specific intubation technique must depend upon the intubator's skill, experience and patient selection.

\section{Intubating guides or introducers}

Intubation using an introducer or guide was first reported by MacIntosh in 1949. ${ }^{3}$ The guide is an elastic catheter (Eschmann gum elastic bougie, Eschmann Health Group, Lancing, West Sussex, UK) with a curved tip at the distal end. This bougie is most suitable for patients whose laryngeal aperture cannot be seen under direct vision using a laryngoscope (Grade III or IV laryngoscopic view as described by Cormack ${ }^{4}$ ). Under these circumstances, the bougie is "hooked" underneath the epiglottis and advanced into the trachea. If it is properly placed, a tactile "clicking" sensation can be felt as the tip of the bougie slides over the tracheal rings while advancing into the trachea. The tracheal tube is then slid over the bougie into the trachea. Following intubation, the positioning of the ETT is confirmed using conventional methods, such as end-tidal $\mathrm{CO}_{2}$ and auscultation.

Many intubating guides with different sizes, shapes, lengths and materials have been developed. All serve a function similar to the gum elastic bougie with some additional features. The Flexguide (Flexguide Division, Scientific Sales International, Inc., Highland Park, IL 60035 , USA) is a flexible plastic introducer with a distal tip which can be mechanically bent by means of a proximal handle. The Sheridan Tube Exchanger (Sheridan, Catheter Corp., Oregon, NY, USA), and Cook Airway Exchange Catheter (Cook Inc., Bloomington, IN, USA) are hollow flexible tubes designed as tube exchangers for patients with difficult airways. In addition, they can be used to ventilate the lungs of patients under difficult circumstances. Recent evaluations have demonstrated the effectiveness of these devices in patients with difficult airways. ${ }^{5-7}$

\section{Augustine guide and stylet}

The Augustine guide is a plastic blade designed to be placed in the vallecula to lift the epiglottis anteriorly so that the Augustine stylet can be inserted into the trachea. The Augustine stylet consists of a hollow shaft catheter with a $35 \mathrm{ml}$ syringe attached at the proximal end, three distal aspiration holes and an S-shape tip at the distal end. The stylet's hollow shaft, distal aspiration holes and proximal syringe function as an oesophageal detector during intubation. The stylet is inserted into the endotracheal tube and together they are preloaded into the channel of the Augustine guide.

During intubation, the tip of the tongue is pulled out

From the Departments of Anaesthesia and Pharmacology, Dalhousie University, Halifax, Nova Scotia, Canada. 
of the mouth by an assistant. The guide is then inserted into the oropharynx so that its tip is placed at the vallecula. This allows the guide to lift the epiglottis upwards to clear a passage for the insertion of the stylet into the trachea. The stylet is advanced into the larynx and trachea. Free aspiration of air by the syringe attached to the stylet suggests correct placement of the stylet in the trachea. Resistance will be encountered during the aspiration if the catheter is accidentally placed in the oesophagus. The ETT is then advanced over the stylet into the trachea. Recent studies have reported successful intubation using this technique in surgical patients with nor$\mathrm{mal}$ and difficult airways. ${ }^{8,9}$

\section{Lighted-stylets (lightwands)}

Intubation using a lightwand was first described by Yamamura in $1959 .{ }^{10}$ This technique uses the principle of transillumination of the soft tissues of the anterior neck and also takes advantage of the anterior location of the trachea relative to the oesophagus. The lightwand is inserted into the ETT so that the light bulb is placed at the distal end of the tube. A $90^{\circ}$ bend is made at the distal end of the ETT just proximal to the cuff in the shape of a "field hockey stick" to improve transillumination. With the patient's head and neck kept in a neutral or slightly extended position, the jaw is lifted upward to clear the epiglottis off the posterior pharyngeal wall. The endotracheal tube and lightwand (ETT-LW) unit is inserted into the oropharynx and is advanced in a midline position. When the tip of ETT-TL enters the glottic opening, a bright circumscribed glow can be seen in the anterior trachea.

Several versions of lightwands have been introduced, including the Fiber Optic Lighted-Intubation Stilette (Benson Medical Industries Inc. Markham, Ont, Canada), Flexilum (Concept Corporation, Clearwater, Fl, USA) Tubestat (10) (Concept Corporation, Clearwater, Fl, USA) Fiberoptic Lighted Stylet (Fiberoptic Medical Products, Inc., Allentown, PA, USA), and Lighted Flexguide (Bay Medical Inc., Clearwater, FL, USA). A new lightwand (Trachlight@), Laerdal Medical Corp., Long Beach, CA) has recently been introduced and consists of a reusable handle, a disposable flexible wand, and a stiff internal retractable stylet. Because of the flexibility of the wand, the device can be used for both oral and nasal intubation. Clinical evaluation of these lightwands suggests that transillumination using these devices may play a major role in tracheal intubation especially in patients with difficult airways. ${ }^{11-13}$

\section{Retrograde intubation}

In 1960, Butler and Cirillo first reported retrograde intubation in surgical patients with an existing tracheostomy opening. ${ }^{14}$ The technique was subsequently modified by Waters who performed a cricothyroid membrane puncture using a Tuohy needle. ${ }^{15}$ Although its clinical acceptance has been overshadowed by the introduction of the intubating technique using a fibreoptic bronchoscope in 1964, retrograde intubation remains an important alternative especially in difficult circumstances. In fact, in 1993, following an extensive review by the ASA difficult airway task force, the retrograde intubation technique was considered to be part of the armamentarium of every anaesthetist. ${ }^{16}$ The technique involves puncture of the cricothyroid membrane using a Tuohy needle. An epidural catheter is inserted through the needle and advanced cephalad so that it can be brought out through the mouth or nose. An ETT is placed over the catheter. While pulling both ends of the catheter taut, the ETT tube is guided into the trachea. Once the ETT enters the trachea, the catheter is pulled out through the mouth or nose.

Modifications of this technique have been developed to improve the success rate of intubation. Bourke suggested that the epidural catheter should be inserted through the "Murphy's" eye of the endotracheal tube. ${ }^{17}$ Others have suggested the use of a guide wire, ${ }^{18}$ guide wire together with a fibreoptic bronchoscope, ${ }^{19}$ subcricoid puncture, ${ }^{20}$ pulling rather than a guided technique, ${ }^{21}$ and multilumen catheter guide ${ }^{22}$ to improve the success rate of the technique. A major deficiency of retrograde intubation relates to the inability to locate the tip of the ETT while advancing it into the glottic opening during intubation.

The presenter uses a modified retrograde intubation technique which involves the use of the classical retrograde technique together with the Trachlight ${ }^{\oplus}$ (with the stiff internal stylet removed). The lightwand serves to confirm the accurate placement of the ETT into the larynx prior to withdrawal of the epidural catheter. The use of an epidural catheter allows easy advancement of the ETT into the trachea. Retrograde intubation is best suited to patients with flexion deformity of the cervical spine, such as those with severe theumatoid arthritis. The epiglottis in these patients frequently touches the posterior pharyngeal wall, making it difficult for the ETT to advance into the larynx.

\section{Digital intubation technique}

Probably the first blind digital orotracheal intubation was described by Herholdt and Rafn in 1796 for the resuscitation of drowning victims. ${ }^{23}$ Although generally not considered to be the preferred technique of intubation, it remains a useful alternative, particularly in the emergency setting when the conventional technique has failed or is not possible due to lack of equipment.

The presenter uses a modified technique which involves 
the use of a stiff, but malleable stylet. The stylet is inserted into the ETT so that the distal end of the stylet is at the level of the "Murphy" eye. With the stylet in place, the distal half of the ETT and the stylet (ETT-ST) unit is bent to a " $U$ " configuration. The proximal half of the ETT is then bent approximately $90^{\circ}$ to the dominant side of the intubator to allow manipulation of the ETTST by the dominant hand during intubation. The patient should be supine with the head in a slight sniffing position. The intubator stands (or kneels if the patient is on the ground) beside the patient so that the nondominant side of the intubator is closest to the patient. Instructing an assistant to pull the tongue forward facilitates the palpation of epiglottis and improves the success rate. The index and middle fingers of the non-dominant hand are inserted into the oral cavity and slid palm down along the surface of the tongue. The tip of the middle finger contacts the tip of the epiglottis which is directed anteriorly. Once the epiglottis is identified, the ETT-ST is inserted through the corner of the mouth. The ETT-ST glides along the groove between the middle and index fingers on the palmar surface of the non-dominant hand. Maintaining firm anterior pressure against the epiglottis with the middle finger, the ETT-ST is advanced slowly into the glottic opening by the dominant hand. The index finger of the non-dominant hand may be used to guide the tip of the ETT-ST into the glottic opening. While withdrawing the stylet, the ETT is slowly advanced into the trachea. The ease and success of digital intubation depends on the intubator's experience, the height of the patient, the mouth opening, the presence of teeth, and the length of the intubator's fingers. During intubation, the ETT-ST should never be advanced forcefully against resistance. This potentially life-saving procedure is relatively simple and can be learned easily. The technique has been used successfully to intubate the tracheas in both neonates and adults in emergency settings. ${ }^{23-25}$

\section{Limitations of these techniques}

While these airways adjuncts and intubating techniques are generally inexpensive, simple to use and effective, they do have limitations. Since direct visualization of the laryngeal structures is not available during intubation using these devices, they should not be used (or used only with great caution in emergency situations) in patients with an abnormality of the upper airways, such as polyp, tumour, foreign body, epiglottitis, and retropharyngeal abscess. Under these conditions, perhaps, intubation using a fibreoptic bronchoscope is more appropriate. For awake intubation in uncooperative patients, a bite block should be placed on one side between the patient's molar teeth to prevent injury to the intubator's fingers or damage to the device.

\section{Conclusion}

Although conventional laryngoscopic intubation is generally effective and safe, occasionally this technique may be difficult. Numerous airway devices and alternative intubating techniques have been developed and have been demonstrated to be effective and life-saving in difficult circumstances. Anaesthetists should become familiar with some of these simple and life-saving "blind" intubating techniques. Successful intubation relies upon the selection and preparation of the patient as well as the skill and experience of the operator in using these techniques. With regular practice, intubation using these devices becomes easier and more successful.

\section{References}

1 Latto IP. Management of difficult intubation. In: Latto IP, Rosen M (Eds.). Difficulties in Tracheal Intubation. London: Bailliere Tindall, 1987: 99-141.

2 Benumof JL. Management of the difficult adult airway. Anesthesiology 1991; 75: 1087-110.

3 MacIntosh RR. An aid to oral intubation. BMJ 1949; 1: 28.

4 Cormack RS, Lehane J. Difficult tracheal intubation in obstetrics. Anaesthesia 1984; 39: 1105-11.

5 Rao TLK, Mathru M, Gorski DW, Salem MR. Experience with a new intubation guide for difficult tracheal intubation. Crit Care Med 1982; 10: 882-3.

6 Nolan $J P$, Wilson $M E$. Evaluation of the gum elastic bougie. Intubation times and incidence of sore throat. Anaesthesia 1992; 47: 878-81.

7 Nolan JP, Wilson ME. Orotracheal intubation patients with potential cervical spine injuries. An indication for the gum elastic bougie. Anaesthesia 1993; 48: 630-3.

8 Carr RJ, Belani KG. Clinical assessment of the Augustine Guide (19) for endotracheal intubation. Anesth Analg 1994; 78: 983-7.

9 Krafft P, Fitzgerald $R$, Pernerstorfer T, Kapral S, Weinstabl $C$. A new device for blind oral intubation in routine and difficult airway management. Eur J Anaesthesiol 1994; 11 : 207-12.

10 Yamamura $H$, Yamamoto $T$, Kamiyama $M$. Device for blind nasal intubation. Anesthesiology 1959; 20: 221.

11 Weis $F R$, Hatton MN. Intubation by use of the lightwand: experience in 253 patients. J Oral Maxillofac Surg 1989; 47: 577-60.

12 Hung OR, Stevens SC, Pytka S, et al. Clinical trial of a new lightwand device for intubation in patients with difficult airways. Anesthesiology 1993; 79: A498.

13 Hammer $M$, Garry B. Transillumination of the trachea with Flexilum. Anesth Analg 1985; 64: 90-3.

14 Butler FS, Circillo AA. Retrograde tracheal intubation. Anesth Analg 1960; 39: 333-8.

15 Waters $D J$. Guided blind endotracheal intubation. Anaesthesia 1963; 18: 159. 
16 Anonymous. Practice guidelines for management of the difficult airway: a report by the American Society of Anesthesiologists Task Force on Management of the Difficult Airway. Anesthesiology 1993; 78: 597-602.

17 Bourke D, Levesque PR. Modification of retrograde guide for endotracheal intubation. Anesth Analg 1974; 53:

1013-4.

18 Gerenstein $R I$. J-wire facilitates translaryngeal guided intubation (Letter). Anesthesiology 1992; 76: 1059.

19 Lechman MJ, Donahoo JS, MacVaugh H. Endotracheal intubation using percutaneous retrograde guidewire insertion followed by antegrade fiberoptic bronchoscopy. Crit Care Med 1986; 14: 589-90.

20 Shantha TR. Retrograde intubation using the subcricoid region. Br J Anaesth 1992; 68: 109-12.

21 Abdou-Madi $M N$, Trop D. Pulling versus guiding: a modification of retrograde guided intubation. Can J Anaesth 1989; 36: 336-9.

22 Dhara SS. Retrograde intubation - a facilitated approach. Br J Anaesth 1992; 69: 631-3.

23 Stewart $R D$. Tactile orotracheal intubation. Ann Emerg Med 1984; 13: 175-8.

24 Woody NC, Woody HB. Direct digital intratracheal intubation for neonatal resuscitation. J Pediatr 1968; 73: 903-5.

25 Hardwick WC, Bluhm D. Digital intubation. J Emerg Med 1984; 1: 317-20. 


\section{Dispositifs d'appoint et techniques alternatives de l'intubation endo- trachéale}

L'intubation endotrachéale constitue un des nombreux défis de l'anesthésiste. Traditionnellement, il introduit dans la trachée un tube endotrachéal (TET) sous vision directe à l'aide d'un laryngoscope. Le succès de l'intubation par laryngoscopie dépend d'abord de l'expérience de celui qui intube et de l'anatomie des voies aériennes du patient. Cependant, même entre les mains d'un laryngoscopiste expérimenté, lintubation sous vision directe peut quelque fois s'avérer difficile ou même impossible. La littérature rapporte que lincidence des intubations difficiles par la laryngoscopie se situe entre 1 et $3 \% .^{.}$Plusieurs caractéristiques anatomiques des voies aériennes permettant de prédire l'intubation difficile ont été identifiées. Cependant, il n'existe aucun paramètre qui puisse prédire à lui seul une intubation difficile par laryngoscopie. $^{2}$ Bien que l'intubation fibroscopique ait fait la preuve de son efficacité dans les cas d'accès difficile aux voies aériennes, elle a ses limitations. Le matériel nécessaire coûte cher et la réalisation de la technique nécessite une formation et une habileté particulières. De plus, cette technique est difficile à exécuter dans les situations urgentes lorsque les sujets sont mal préparés ou ne collaborent pas ou lorsque les patients ont des sécrétions abondantes ou du sang dans l'oropharynx. Pendant les dernières décennies, la fréquence des conditions d'intubation difficiles a suscité le développement de plusieurs instruments d'appoint et de techniques comme alternatives à l'intubation. L'objectif principal de cette présentation n'est pas de fournir une liste exhaustive de toutes les techniques et de tous instruments d'appoint, mais plutôt de revoir quelques techniques anciennes et les nouveaux développements réalisés ces dernières années dans le domaine de lintubation à l'aveugle. Il faut aussi mentionner que cette présentation reflète uniquement l'expérience de celui qui parle et quil n'exprime que son opinion personnelle avec le matériel dont il dispose. Le choix de la technique spécifique d'intubation doit dépendre de lhabileté de celui qui intube, de son expérience et du patient quil faut intuber.

\section{Mandrins et introducteurs}

L'intubation à l'aide d'un introducteur ou un mandrin a été d'abord décrite par Macintosh en 1949. ${ }^{3}$ Le mandrin est constitué d'un cathéter élastique (la bougie en gomme élastique d'Eschmann, Eschmann Health Group, Lancing, West Sussex, Grande Bretagne) avec une extrémité distale incurvée. Cette bougie convient surtout au patient dont l'ouverture laryngée ne peut être approchée sous vision directe avec un laryngoscope (Grade III et IV tels que décrits par Cormack). ${ }^{4}$ Dans ces circonstances, la bougie est recourbée sous l'épiglotte et avancée dans la trachée. Si sa position est correcte, une sensation de déclic tactile est ressentie lorsque la bougie glisse sur les anneaux trachéaux pendant sa progression trachéale. Le tube endotrachéal est alors glissé sur la bougie et poussé dans la trachée. Après l'intubation, la position du TET est confirmée par les méthodes conventionnelles comme la capnographie et l'auscultation.

Plusieurs mandrins dintubation de dimension, forme, longueur, et en matériaux variés ont été développés. Ils ont tous la même fonction que la bougie en gomme élastique et souvent quelques caractéristiques additionnelles. Le Flexguide (Flexguide Division, Scientific Sales International, Inc., Highland Park, IL 60035, EUA) est un introducteur flexible en plastique dont le bout distal peut être mécaniquement recourbé au moyen d'une poignée proximale. Le tube d'échange Sheridan (Sheridan $\mathrm{Ca}$ theter Corp., Oregon, NY, EUA), et le cathéter d'échange Cook (Cook Inc., Bloomington, IL, EUA) sont des sondes flexibles destinées aux échanges de tube chez les patients qui ont des voies aériennes d'accès difficile. De plus, on peut les utiliser pour ventiler les patients dans des situations d'urgence. Des évaluations récentes on montré l'efficacité de ces instruments. ${ }^{5-7}$

\section{Le guide et le stylet d'Augustine}

Le guide d'Augustine est une lame de plastique destinée à la vallécula; une fois introduit, il permet de soulever l'épiglotte antérieurement de façon à ce que le stylet d'Augustine puisse être inséré à son tour dans la trachée. Le stylet lui-même est constitué d'une sonde adaptée par son extrémité proximale à une seringue de $35 \mathrm{ml}$, trois ouvertures distales pour l'aspiration et une pointe en forme de $\mathrm{S}$ à son extrémité distale. La tige creuse du stylet, 
les orifices d'aspiration distaux fonctionnent comme un détecteur oesophagien durant l'intubation. Le stylet est inséré dans le tube endotrachéal et ensemble ils sont introduits dans le canal formé par le guide d'Augustine.

Pendant l'intubation, le bout de langue est tiré hors de la bouche par un assistant. Le guide est alors inséré dans l'oropharynx de sorte que son extrémité est placée dans la vallécula. Ceci permet au guide de soulever l'épiglotte vers le haut et de dégager un passage pour linsertion du stylet dans la trachée. Le stylet est avancé dans le larynx et la trachée. Si l'air est facilement aspiré dans la seringue attachée au stylet, on peut assumer que le placement du stylet est correct. Si le cathéter est accidentellement introduit dans l'oesophage, on rencontre une résistance pendant l'aspiration. Le cas échéant, le TET est alors poussé sur le stylet vers la trachée. Des études récentes ont rapporté avec cette technique la réussite de lintubation tant chez des patients aux voies aériennes normales que difficiles. ${ }^{8,9}$

\section{Les guides lumineux (mandrins lumineux)}

L'intubation à l'aide d'un mandrin lumineux a été d'abord décrite par Yamamura en 1959. ${ }^{10}$ Cette technique utilise le principe de la transillumination des tissus mous de la région cervicale antérieure et profite de l'avantage de la localisation antérieure de la trachée relativement à l'oesophage. Le mandrin lumineux est inséré dans le TET de façon à ce l'ampoule lumineuse rejoigne l'extrémité distale du tube. Une courbe de $90^{\circ}$ en forme de bâton de hockey est préformée à l'extrémité distale du TET à proximité de la manchette pour faciliter la transillumination. Avec la tête et le cou en position neutre ou en légère extension, la mâchoire du sujet est soulevée vers le haut de façon à dégager l'épiglotte de la paroi pharyngée postérieure. Le TET et le mandrin lumineux (TET-ML) sont insérés en bloc dans l'oropharynx et avancés en position médiane. Quand le bout du TET pénètre dans l'orifice glottique, une lueur circonscrite et brillante peut être aperçue a travers la trachée antérieure.

Plusieurs versions du mandrin lumineux ont été fabriquées, incluant le guide illuminé à fibres optiques pour intubation (Benson Medical Industries Inc. Markham, Ont., Canada), le Flexilum (Concept Corporation, Clearwater, FL, EUA), le Tubestat (10) (Conception Corporation, Clearwater, FL, EUA), le mandrin lumineux à fibres optiques (Fiberoptic Medical Products, Inc., Allentown, PA, EUA), et le Lighted Flexguide (Bi) (Bay Medical Inc., Clearwater, FL, EUA). Un nouveau mandrin lumineux (Trachlightiî, Laerdal Medical Corp., Long Beach, CA) a récemment commercialisé; il est constitué d'une poignée réutilisable avec un mandrin lumineux flexible et un stylet interne rigide rétractable. A cause de la flexibilité du mandrin, cet appareil peut être utilisé à la fois pour l'intubation orale et nasale. L'évaluation de ces mandrins lumineux suggère que la transillumination pourrait, grâce à ces appareils, occuper une place plus importante parmi les techniques dintubation de la trachée spécialement chez les patients dont l'accès aux voies aériennes est difficile. ${ }^{11-13}$

\section{Lintubation rétrograde}

En 1960, Butler et Cirillo ont décrit lintubation rétrograde chez un trachéostomisé. ${ }^{14} \mathrm{La}$ technique a été par la suite reprise par Waters qui l'a complétée par une ponction de la membrane cricothyroïdienne avec une aiguille Tuohy. ${ }^{15}$ Bien que son utilisation ait été restreinte depuis l'introduction de la technique fibroscopique dintubation en 1964, lintubation rétrograde demeure une alternative valable dans des circonstances spéciales. En réalité, en 1993, après une revue exhaustive de l'intubation difficile par le groupe d'étude ad hoc de l'ASA, la technique d'ntubation rétrograde a été reconsidérée comme faisant partie intégrale de l'arsenal technique de l'anesthésiste. ${ }^{16} \mathrm{La}$ technique nécessite une ponction de la membrane cricothyroïdienne avec une aiguille Tuohy. Un cathéter épidural est passé à travers l'aiguille et avancé vers la tête de sorte quil apparaîtra dans la bouche ou le nez. Un TET est enfilé sur le cathéter. Alors que les deux extrémités du cathéter sont tendues, le TET est guidé dans la trachée. Une fois le. TET introduit dans la trachée, le cathéter est retiré par la bouche ou le nez.

Des modifications ont été apportées à cette technique pour améliorer son taux de succès. Bourke a suggéré que le cathéter épidural soit inséré à travers l'oeil de Murphy du tube endotrachéal. ${ }^{17}$ D'autres proposent d'utiliser un fil métallique, ${ }^{18}$ un guide métallique combiné à un bronchoscope à fibres optiques, ${ }^{19}$ une ponction souscricoidienne, ${ }^{20}$ une technique de traction plutôt quiun simple passage ${ }^{21}$ et un guide constitué d'un cathéter à plusieurs lumières ${ }^{22}$ pour améliorer le taux de succès de la technique. L'incapacité de localiser l'extrémité du TET lorsqu'on l'avance dans l'ouverture glottique pendant l'intubation représente la principale faiblesse de l'intubation rétrograde.

Votre interlocuteur utilise une technique d'intubation rétrograde modifiée qui combine la technique rétrograde classique avec le Trachlight(ii) (sans stylet interne). Le mandrin lumineux sert à confirmer le placement correct du TET dans le larynx avant le retrait du cathéter épidural. Lutilisation d'un cathéter épidural permet d'avancer facilement le TET dans la trachée. Lintubation rétrograde est particulièrement indiquée chez les patients porteurs d'une difformité en flexion de la colonne cervicale comme dans l'arthrite rhumatoïde avancée. Chez ces patients, l'épiglotte touche fréquemment la paroi pharyngée postérieure, ce qui rend le TET difficile à avancer. 


\section{Technique d'intubation digitale}

La première intubation orotrachéale digitale à l'aveugle a probablement été décrite la première fois par Herholdt et Rafn en 1796 pour la réanimation des victimes de noyade. ${ }^{23}$ Bien qu'on ne puisse considérer cette technique d'intubation comme une technique de choix, elle demeure une alternative utile, particulièrement dans des circonstances urgentes quand la technique conventionnelle a échoué ou est impossible par manque de matériel.

Votre interlocuteur utilise une technique modifee qui nécessite l'usage d'un stylet rigide tout en étant malléable. Le stylet est introduit dans le TET de sorte que l'extrémité du stylet est au niveau de l'oeil de Murphy. Avec le stylet en place, la moitié distale du TET et le stylet (TET-ST) sont courbés en forme de U. La moitié proximale du TET est alors recourbée approximativement à $90^{\circ}$ du côté prédominant de lintubateur pour permettre à celui-ci de manipuler le TET-ST avec sa main prédominante pendant lintubation. Le malade doit être couché sur le dos avec la tête maintenue en position du renifleur " sans exagération ". L'intubateur se tient debout (ou à genoux si le malade est couché sur le sol), à côté du patient de sorte que le côté non prédominant de l'intubateur est le plus près du patient. Si on donne l'ordre à un assistant de tirer la langue en avant, ceci facilite la palpation de l'épiglotte et augmente le taux de succès. L'index et le médius de la main non prédominante sont insérés dans la cavité orale et glissé avec la paume de la main vers le bas le long de la surface de la langue. Le bout du médius contacte le bout de l'épiglotte qui est dirigée antérieurement. Une fois l'épiglotte identifiée, le TET-ST est inséré par le coin de la bouche. Le TET-ST glisse dans le sillon formé entre le médius et l'index sur la surface palmaire de la main non prédominante. En maintenant une pression antérieure ferme contre l'épiglotte avec le médius, le TET-ST est avancé lentement dans l'ouverture glottique par la main prédominante. Lindex de la main non prédominante peut être utilisé pour diriger le bout du TET-ST dans l'ouverture glottique. Tout en retirant le stylet, le TET est avancé lentement dans la trachée. La facilité et le succès de l'intubation digitale dépendent de l'expérience de lintubateur, de la taille du sujet, de l'ouverture de la bouche, de la présence de dents, et de la longueur des doigts de l'intubateur. Pendant l'intubation, le TET-ST ne devrait jamais être poussé avec force contre une résistance. Cette procédure de sauvetage est relativement simple et peut être apprise facilement. Cette technique a été utilisée avec succès pour intuber à la fois des nouveau-nés et des adultes dans des situations d'urgence. $^{23-25}$

Limite de ces techniques

Bien que ces instruments d'appoints et ces techniques d'in- tubation soient généralement peu coûteux, simples à utiliser et efficaces, ils ont des limitations. Comme avec ces appareils la visualisation des structures laryngées ne peut être réalisée pendant l'intubation, ils ne devraient pas être utilisés (ou seulement avec extrême prudence dans les situations d'urgence) chez des patients qui ont une anomalie des voies respiratoires supérieures, comme des polypes, des tumeurs, des corps étrangers, une épiglottite ou un abcès rétropharyngés. Dans ces circonstances, il est plus approprié d'utiliser la fibroscopie. Pour lintubation éveillée et chez les malades qui ne coopèrent pas, une butée devrait être placée unilatéralement entre les molaires du patient pour protéger la main de l'intubateur et éviter des dommages aux instruments.

\section{Conclusion}

Bien que l'intubation par laryngoscopie conventionnelle soit généralement efficace et sans danger, à l'occasion, cette technique peut s'avérer difficile. Plusieurs dispositifs pour l'intubation et certaines techniques alternatives ont montré leur efficacité pour l'intubation normale et comme mesures de sauvetage en situations d'urgence. Les anesthésistes devraient être familiers avec quelques-unes de ces méthodes d'intubation à l'aveugle simples mais importantes. Le succès de lintubation dépend de la sélection et de la préparation du patient aussi bien que de l'habileté et de l'expérience de celui qui utilise ces techniques. Avec des pratiques régulières, l'intubation assistée par ces dispositifs deviendra plus facile et réussira plus souvent.

\section{Références}

(Voir page R33) 